\title{
Pericardial Fluid in a COVID-19 Patient: Is It Exudate or Transudate?
}

\author{
Hassan H Allam ${ }^{1}$, Abdulhalim J Kinsara ${ }^{2}$, Tareq Tuaima ${ }^{1}$, Shadwan Alfakih ${ }^{1}$ \\ ${ }^{1}$ King Abdullah Medical Complex, Jeddah, Ministry of Health, Jeddah, Saudi Arabia \\ ${ }^{2}$ Ministry of National Guard-Health Affairs, King Saud Bin Abdulaziz University for Health Sciences, COM-WR, King Abdullah International Medical \\ Research Center, Jeddah, Saudi Arabia
}

Received: 02/05/2020

Accepted: 05/05/2020

Published: 12/05/2020

How to cite this article: Allam HH, Kinsara AJ, Tuaima T, Alfakih S. Pericardial fluid in a COVID-19 patient: is it exudate or transudate? EJCRIM 2020;7: doi:10.12890/2020_001703.

Conflicts of Interests: The Authors declare that there are no competing interests.

This article is licensed under a Commons Attribution Non-Commercial 4.0 License

\section{ABSTRACT}

Background: Very limited information is available on pericardial effusion as a complication of COVID-19 infection. There are no reports regarding pericardial fluid findings in COVID-19 patients.

Case description: We describe a 41-year-old woman, with confirmed COVID-19, who presented with a large pericardial effusion. The pericardial fluid was drained. We present the laboratory findings to improve knowledge of this virus.

Discussion: We believe this is the first such reported case. Findings suggested the fluid was exudative, with remarkably high lactate dehydrogenase and albumin levels. We hope our data provide additional insight into the diagnosis and therapeutic options for managing this infection.

\section{LEARNING POINTS}

- Laboratory findings of drained pericardial fluid in a patient with COVID-19 are presented.

- The clinical presentation of pericardial involvement in COVID-19 infection and the role of echocardiography in diagnosis and management are described.

\section{KEYWORDS}

Pericardial effusion, COVID-19, pericardiocentesis

\section{INTRODUCTION}

Cardiac involvement has been described in patients with COVID-19 infection ${ }^{[1,2]}$. There have been no previous reports on pericardial fluid characteristics in COVID-19 patients or on diagnostic criteria for determining whether such fluid is transudate or exudate. To the best of our knowledge we present the first such case.

\section{CASE DESCRIPTION}

A 41-year-old female patient was referred to our hospital with COVID-19 and pericardial effusion. She had been admitted to the referring hospital 10 days previously with a sore throat, cough and shortness of breath. Her medical history was negative for chronic disease, but she had been in contact with an individual with COVID-19.

Her clinical findings were as follows: temperature $37.1^{\circ} \mathrm{C}$, heart rate $105 \mathrm{bpm}$, blood pressure $125 / 85 \mathrm{mmHg}$, and oxygen saturation $98 \%$ on 2 litres of oxygen. Laboratory findings are given in Table 1. The ECG showed sinus tachycardia, with no ischaemic changes. An echocardiogram demonstrated a large pericardial effusion, with early signs of tamponade in the form of right atrial systolic collapse (Fig. 1). 
A chest $x$-ray revealed cardiomegaly, and smooth cardiac boarders suggestive of pericardial effusion (Fig. 2). A CT scan of the chest showed ground-glass opacities in the right and left lower lung lobes and a large pericardial effusion. A nasal swab was positive for COVID-19.

\begin{tabular}{|c|c|c|c|}
\hline & Pericardial fluid & Blood & Comments \\
\hline Appearance & Clear & & \\
\hline Colour & Yellow & & \\
\hline $\begin{array}{l}\text { White blood cell } \\
\text { (WBC) count }\end{array}$ & $\begin{array}{l}156 \text { cells } / \mathrm{ml} \\
\text { (normal }<5 \text { cells } / \mathrm{ml} \text { ), } \\
\text { mainly mesothelial cells and } \\
\text { macrophages (reactive), } \\
\text { a few monocytes }(<1 \%) \text { and a } \\
\text { few neutrophils }(<0.5 \%)\end{array}$ & $\begin{array}{l}7.5109 / \mathrm{L} \\
\text { (normal count and differential) }\end{array}$ & $\begin{array}{l}\text { Platelets } \\
455 \times 109 / / \\
(150-400)\end{array}$ \\
\hline $\begin{array}{l}\text { Red blood cell } \\
\text { (RBC) count }\end{array}$ & $>10$ & & $\mathrm{Hb} 11 \mathrm{~g} / \mathrm{dl}$ \\
\hline Glucose & $5.3 \mathrm{mmol} / \mathrm{l}$ & $5.3 \mathrm{mmol} / \mathrm{l}$ & Transudate \\
\hline Total protein & $27.8 \mathrm{~g} / \mathrm{l}$ & $64 \mathrm{~g} / \mathrm{l}$ & Transudate \\
\hline Albumin & $18.4 \mathrm{~g} / \mathrm{l}$ & $17.9 \mathrm{~g} / \mathrm{l}$ & Exudate \\
\hline \multirow{3}{*}{$\begin{array}{l}\text { Lactate } \\
\text { dehydrogenase } \\
\text { (LDH) }\end{array}$} & $68 \mathrm{U} / \mathrm{I}$ & $56 \mathrm{U} / \mathrm{I}$ & Exudate \\
\hline & & $\begin{array}{l}\text { C-reactive protein normal } \\
\text { Erythrocyte sedimentation rate } \\
25(0-20) \\
\text { Troponin } 10.000 \mu \mathrm{g} / \mathrm{l} \\
(0.020-0.060) \\
\text { Ferritin serum } 20 \mu \mathrm{g} / \mathrm{l}(10-291)\end{array}$ & \\
\hline & & $\begin{array}{l}\text { Liver function tests, creatinine } \\
\text { and thyroid function tests } \\
\text { normal }\end{array}$ & \\
\hline
\end{tabular}

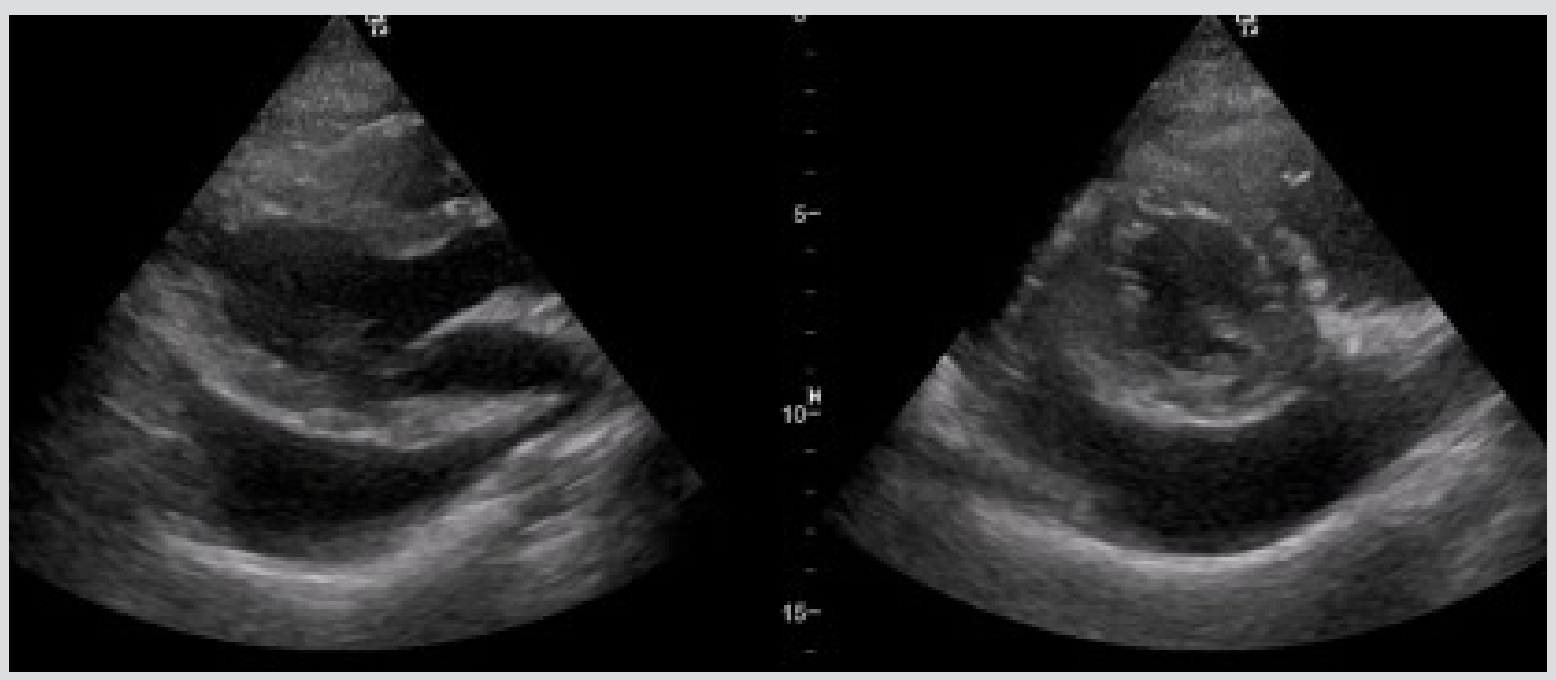

Figure 1. Echocardiogram showing a large pericardial effusion 
The patient was reviewed and managed according to the COVID-19 protocol. Deep vein thrombosis prophylaxis and stress ulcer prophylaxis were initiated. Investigation of the pericardial effusion included an autoimmune screen and thyroid profile.

In view of the patient's symptoms and the echo findings, pericardial aspiration was performed aseptically with appropriate PPE, and 550 $\mathrm{ml}$ of pericardial fluid was drained.

We concluded that the pericardial fluid was most likely exudative, with remarkably high lactate dehydrogenase (LDH) and albumin levels. The patient was started on azithromycin $500 \mathrm{mg}$ once daily for 3 days and hydroxychloroquine 200 mg twice daily. The patient had improved significantly by day 2 , and was discharged well on day 6 to continue isolation at home.

\section{DISCUSSION}

Coronavirus disease 19 was recently identified in China and is spreading across the globe ${ }^{[1,2]}$. Symptoms are mostly respiratory but cardiac involvement has also been reported ${ }^{[3]}$. Cardiac involvement usually consists of myocarditis but the spectrum is widening as more cases are reported. Incidental pericardial effusion has been reported in $4.55 \%$ of all CT scans of the chest ${ }^{[4]}$. Our case seems to be unique, as the pericardial fluid was drained. The pericardial fluid showed elevated LDH and WBC, while glucose levels were unchanged.

In conclusion, to the best of our knowledge, we have described the first analysis of pericardial fluid in a COVID-19 patient with a large pericardial effusion. We hope our data provide additional insights into the diagnosis and therapeutic options for managing this infection.

\section{REFERENCES}

1. World Health Organization. Novel coronavirus - China. Available from: https://www.who.int/csr/don/12-january-2020-novel-coronavirus-china/en/ (accessed 6 May 2020).

2. Huang C, Wang Y, Li X, Ren L, Zhao J, Hu Y, et al. Clinical features of patients infected with 2019 novel coronavirus in Wuhan, China. Lancet 2020;395:497-506.

3. Li K, Wu J, Wu F, Guo D, Chen L, Fang Z, et al. The clinical and chest CT features associated with severe and critical COVID-19 pneumonia. Invest Radiol 2020;55(6):327-331.

4. Bao C, Liu X, Zhang H, Li Y, Liu J. Coronavirus disease 2019 (COVID-19) CT findings: a systematic review and meta-analysis. J Am Coll Radiol 2020 Mar 25. pii: S15461440(20)30262-3. doi: 10.1016/j.jacr.2020.03.006 [Epub ahead of print]. 